\title{
Attitude, Awareness and Usage Skills of Computer and Internet among Medical Students
}

\author{
Dr. Nagasireesha Challa ${ }^{1}$, Dr. Venkatachalam Madras ${ }^{2}$ \\ ${ }^{1}$ Assistant professor, Dept. of Physiology, S.V.Medical College, Tirupati, India \\ ${ }^{2}$ Professor, Dept. of Physiology, S.V.Medical College, Tirupati, India.
}

\begin{abstract}
:
Background: The aim of this study is to assess the pattern of computer and internet use among the undergraduate medical students of S.V.Medical College, Tirupati. Methods: 180 first year medical students participated in the study. A questionnaire was designed to know their level of computer and internet usage skills. Results: Maximum number of students was aged 18 with $60 \%$ females. Among the users, $88.3 \%$ have own computer at home and majority are using it for entertainment. $68.89 \%$ have average computer skill and majority use internet daily or every alternate day. Majority (78.89\%) is satisfied with computer assisted teaching and many would like to have short training courses for acquiring computer knowledge in their institution. Conclusion: The study shows that majority of medical students had experience with computer and internet, but the frequency, pattern and purpose of use is variable. More facilities should be available to the students regarding computer and internet for better utilization of internet resources.
\end{abstract}

Keywords: computer, internet, medical students, knowledge

\section{Introduction}

Several developed countries have chosen Information Technology (IT) as one of the comprehensive learning objectives to be used as a guide for medical education. The entrenchment of IT into medical school curricula was designed to promote the use of computer technology to enhance student's scientific and medical knowledge ${ }^{[1]}$. One of the major goals of medical education is to encourage students to maintain their knowledge of medical science by becoming lifelong learners. Adequate skills in information seeking and regular use of original scientific sources are key elements in this process ${ }^{[2,3]}$.

Digital divide is used to describe the increasing gap between computer users and non-users. It is the division of the world between those who have access to new ICT (Information and Computer Technology) and those who do not ${ }^{[4]}$. In September 2000, the digital divide was highlighted by the World Health Organization as "more dramatic than any other inequity in health or income" ${ }^{[5,6]}$. The advantages of information technology would be mirage if the medical students lack adequate computer skills and the necessary resources are not made available to ensure that they achieve substantive computer literacy to access and evaluate web-based information ${ }^{[1]}$. The introduction of computer-aided learning has not attracted significant attention in developing countries like India ${ }^{[7]}$. The present study was conducted to study the pattern of computer and internet usage, to evaluate the knowledge and skills in utilization of computer and internet by medical students in our institution.

\section{Materials And Methods}

The present study was conducted in Sri Venkateswara Medical College, Tirupati. The study was approved by the Institutional Ethical Committee. The study was undertaken using first year undergraduate students to identify the basic skills in using computer and internet. A self administered questionnaire designed for the study was given to the students. Students were educated on the purpose of the study and contents and completion of questionnaire. They were told that the data was confidential and for research purpose only. Verbal consent was taken from the participants. Estimated time to complete the questionnaire was ten minutes. The returned questionnaires were checked for completeness and consistency. Improperly filled questionnaires are excluded. A total of 180 questionnaires were used for analysis. All the data was collected at the end of the study and presented in percentage

\section{Results}

Demographic profile of students shows that maximum number of students who participated in the study was of 18 years age. Among them 72 were males (40\%) and 108 were females (60\%). 
TABLE-1

Baseline characteristics of the study population $(\mathrm{N}=180)$

\begin{tabular}{|c|c|c|c|}
\hline S. No. & Characteristics & Number & $\begin{array}{c}\text { Percentage } \\
(\mathbf{\%})\end{array}$ \\
\hline 1. & Age Group (yrs) & 40 & 22.22 \\
& $<18$ & 96 & 53.34 \\
& 18 & 44 & 24.44 \\
\hline 2. & $>18$ & & \\
& Gender & 72 & 40 \\
& Male & 108 & 60 \\
\hline
\end{tabular}

TABLE-2

Pattern of use of computers among medical students

\begin{tabular}{|c|c|c|c|}
\hline S. No. & Pattern of computer use & $\begin{array}{c}\text { Number } \\
\mathrm{N}=180\end{array}$ & Percentage (\%) \\
\hline 1 & $\begin{array}{l}\text { Do you own computer/ laptop/tablet/any other mobile } \\
\text { appliances from which you can access internet? } \\
\text { (a)Yes } \\
\text { (b)No }\end{array}$ & $\begin{array}{c}159 \\
21 \\
\end{array}$ & $\begin{array}{l}88.3 \\
11.7 \\
\end{array}$ \\
\hline 2 & $\begin{array}{l}\text { Purpose of using computer } \\
\text { (a)Academic } \\
\text { (b)Social networking } \\
\text { (c)Entertainment/ Others }\end{array}$ & $\begin{array}{c}26 \\
53 \\
101\end{array}$ & $\begin{array}{l}14.45 \\
29.45 \\
56.10\end{array}$ \\
\hline 3 & $\begin{array}{l}\text { Place where you use computers mostly? } \\
\text { (a)Home/Hostel } \\
\text { (b)Internet cafe/ Others }\end{array}$ & $\begin{array}{c}169 \\
11\end{array}$ & $\begin{array}{c}93.89 \\
6.11\end{array}$ \\
\hline 4 & $\begin{array}{l}\text { Method of acquiring knowledge of computer? } \\
\text { (a)Self } \\
\text { (b)Friends/family members } \\
\text { (c)Attending training programme }\end{array}$ & $\begin{array}{c}15 \\
150 \\
15\end{array}$ & $\begin{array}{c}8.33 \\
83.34 \\
8.33\end{array}$ \\
\hline 5 & $\begin{array}{l}\text { First use of computer? } \\
\text { (a)Before joining medical college } \\
\text { (b)After joining medical college }\end{array}$ & $\begin{array}{c}109 \\
71\end{array}$ & $\begin{array}{l}60.55 \\
39.45\end{array}$ \\
\hline
\end{tabular}

TABLE-3

Use of internet among study population

\begin{tabular}{|c|c|c|c|}
\hline S. No. & Pattern of use of Internet resources & $\begin{array}{c}\text { Number } \\
\mathbf{N}=180\end{array}$ & Percentage (\%) \\
\hline 1 & $\begin{array}{l}\text { Skill in using computer and internet } \\
\text { (a)Unfamiliar } \\
\text { (b)Beginner } \\
\text { (c)Average } \\
\text { (d)Competent } \\
\text { (e)Expert }\end{array}$ & $\begin{array}{c}5 \\
29 \\
124 \\
20 \\
2\end{array}$ & $\begin{array}{c}2.78 \\
16.11 \\
68.89 \\
11.11 \\
1.11\end{array}$ \\
\hline 2 & $\begin{array}{l}\text { You are getting information preferably from } \\
\text { (a)Internet } \\
\text { (b)Text books } \\
\text { (c)Journals \& Others }\end{array}$ & $\begin{array}{c}115 \\
60 \\
5\end{array}$ & $\begin{array}{c}63.89 \\
33.33 \\
2.78 \\
\end{array}$ \\
\hline 3 & $\begin{array}{l}\text { Reasons for preferring internet } \\
\text { (a)Easy accessibility } \\
\text { (b)Latest knowledge } \\
\text { (c)Time saving }\end{array}$ & $\begin{array}{c}63 \\
105 \\
12 \\
\end{array}$ & $\begin{array}{c}35.00 \\
58.33 \\
6.67 \\
\end{array}$ \\
\hline 4 & $\begin{array}{l}\text { Frequency of using internet } \\
\text { (a)Daily } \\
\text { (b)2-3 days in a week } \\
\text { (c)Monthly } \\
\text { (d)Rarely }\end{array}$ & $\begin{array}{l}65 \\
61 \\
16 \\
38\end{array}$ & $\begin{array}{c}36.11 \\
33.89 \\
8.89 \\
21.11\end{array}$ \\
\hline 5 & $\begin{array}{l}\text { Are you satisfied with computer assisted teaching? } \\
\text { (a)Yes } \\
\text { (b)No }\end{array}$ & $\begin{array}{c}142 \\
38\end{array}$ & $\begin{array}{l}78.89 \\
21.11\end{array}$ \\
\hline 6 & $\begin{array}{l}\text { Should computer \& internet use be encouraged in medical colleges? } \\
\text { (a)Yes } \\
\text { (b)No }\end{array}$ & 173 & 96.11 \\
\hline
\end{tabular}




\begin{tabular}{|l|l|c|c|}
\hline & & 7 & 3.89 \\
\hline 7 & Do you want computer training to be conducted in your institution? & & \\
& (a)Yes & & \\
& (b)No & 103 & 57.22 \\
& & 77 & 42.78 \\
\hline 8 & Do you agree that internet has positive impact on academic performance? & & \\
& (a)Agree & \multirow{2}{*}{174} & 96.67 \\
& (b)Disagree & 6 & 3.33 \\
\hline
\end{tabular}

Student's ability to use computer is presented in Table II. It was observed that $159(88.3 \%)$ students had their own computer or other appliances from which internet can be accessed. The majority of students (56.1\%) use it for entertainment, $29.45 \%$ use it for social networking and only $14.45 \%$ are using for academic purpose. The majority of students 169 (93.89\%) use computer at home or hostel, while $11(6.11 \%)$ use internet cafes. Most $(83.34 \%)$ of them learnt using computer and internet from their friends and family members while $8.33 \%$ learnt from attending training programme. It was observed that majority $60.55 \%$ first started using internet before joining medical college while $39.45 \%$ started after joining medical college.

While evaluating their computer literacy, most of the students consider themselves $(68.89 \%)$ as an average user. $11.11 \%$ considered themselves as competent and $1.11 \%$ as experts. Few of them $(2.78 \%)$ are unfamiliar of using computer and internet. we found that $63.89 \%$ students prefer internet to get required information while $33.33 \%$ prefer textbooks and $2.78 \%$ prefer journals and other media. Majority of students preferred internet over textbooks because of getting latest knowledge $(58.33 \%)$ and $35 \%$ preferred it for easy accessibility, while $6.67 \%$ preferred for time saving.

$36.11 \%$ of students are using internet daily, $33.89 \%$ twice or thrice in a week, $8.89 \%$ monthly and $21.11 \%$ rarely. $96.11 \%$ of students are in favor of using computer and internet in teaching institutions. $78.89 \%$ of students were satisfied with computer assisted teaching while $21.11 \%$ were not. $57.22 \%$ of students want training to be conducted in computer skills in their institution. $96.67 \%$ of students agree that the internet has a positive impact on academic performance.

\section{Discussion}

The present study evaluated the awareness and utilization of internet among medical students. We found substantial limitations in computing skills among both male and female students. From the study, $88.3 \%$ have their own personal computer or other appliance through which internet can be accessed. It is more among the college students of Mangalore, India ${ }^{[2]}$ and also more than the $(66.8 \%)$ study group of Bangladesh ${ }^{[3]}$. This is encouraging and might be due to affordability and also the easy availability of new generation of mobiles from which internet can be accessed and they can be carried easily.

In our study, we found that $85.55 \%$ of medical students use computers for recreational purposes and only $14.45 \%$ uses it for academic purpose. This is similar to the study of Unnikrishnan et al. and Chowdhury NS et al.

In this study, we found that majority of medical students use computers at home or hostel. This is also similar to the study of Unnikrishnan et al. It may be because of affordability of the students.

It was seen that majority of students first started using the internet before arriving at college. It is in similarity with the findings of Unnikrishnan et al., but in controversy with the study conducted in America ${ }^{[8]}$. This suggests the increasing access and usage of internet by students during the past few years.

The preferred medium for getting information among the students in the present study was the internet followed by textbooks. This indicates that the use of internet is increasing for getting required information. Unnikrishnan et al. showed similar results whereas the studies by Sharma et al. ${ }^{[9]}$ showed that the textbook was preferred medium for most of the undergraduate medical students.

In the study, we found that only $36.11 \%$ of students use internet daily which is lower as compared to those from other countries ${ }^{[10,11]}$. Students must be encouraged to use electronic resources for their studies.

In our study, majority of students advocated that computer and internet use should be encouraged in teaching institutions which is comparable with the study of Unnikrishnan et al. and Sharma et al. The computer assisted teaching is gaining importance in the medical teaching as students can have various illustrations.

More than half of the students want computer training in their institution and majority agree that the computer supplement to medical teaching. This is in similar with studies of Fadeyi et al. and Unnikrishnan et al. who recommended formal computer training programs for undergraduate medical students.

Our study has its limitations. The present study was conducted at a single government tertiary care teaching hospital. But, the environment and educational resources may be different in private medical colleges. As the cost of telecommunications decreases and the speed of telecommunications increases, new forms of computer communication, such as long-distance, real-time audio and video services will become available. 
Computer networks in general and the internet in particular are likely to play more important roles in many aspects of medicine in the future ${ }^{[12]}$.

\section{Conclusion}

In conclusion, although majority of the study subjects are experienced with use of internet, they are not utilizing it properly as a learning tool in their education. The frequency, pattern and purpose of use are variable. Students are using computer and internet for entertainment and social networking rather than acquiring medical knowledge. Computer and internet are likely to play more important roles in many aspects of medicine in future. Attention should be paid to develop interventions that can improve computer usage skills, and to improve computer access. Short training courses in computer application and internet use is recommended in medical colleges. Students should be trained to get valuable information from the websites. Computer assisted teaching should be encouraged in all medical colleges. In addition, participation in medical research work/thesis can enhance computer skills. Such activities should be encouraged in all medical institutions.

\section{Acknowledgement}

We would like to express our gratitude to all the medical students who participated in the study.

\section{References}

[1] Fadeyi A, Desalu OO, Ameen A,Muhammed Adeboye AN. The reported preparedness and disposition by students in a Nigerian university towards the use of information technology for medical education. Annals of African Medicine Vol.9, No.3; 2010:129-34

[2] Unnikrishnan B, Kulshrestha V, Saraf A, Agrahari AC, Prakash S, Samantaray L, Parida A. Pattern of computer and internet use among medical students in Coastal South India. South East Asian Journal of Medical Education,Vol. 2 no. $2,2008$.

[3] Nasrin Sultana Chowdhury, Nurun Nahar Chowdhury, Ferdous Rabbi, Rehnuma Tabassum, Sonia Ishrat. Computer Literacy and Attitudes Towards e-learning among Bangladeshi Medical Students. Updat Dent. Coll. J 2013; 3(1): 3-6.

[4] Uzunboylu, H., \& Tunkey, N. (2010) Divergence of Digital World of Teachers. Educational Technology \& Society, 13(1), 186-194.

[5] Edeger TT: Disseminating health information in developing countries: the role of the internet. BMJ 2000, 321:797-800.

[6] Miriam Samuel, John C Coombes, J Jaime Miranda, Rob Melvin, Eoin JW Young and Pejman Azarmina. Assessing computer skills in Tanzanian medical students: an elective experience. BMC Public Health 2004, 4:37.

[7] Panchabhai TS, Dangayach NS, Mehta VS, Patankar CV, Rege NN. A cross-sectional evaluation of computer literacy among medical students at a tertiary care teaching shospital in Mumbai (Bombay). Journal of Postgraduate Medicine, 2011, Volume 57, Issue 1.

[8] Steve Jones. The Internet Goes to College, Internet \& American life. Sep 15,2002 [available from http://www.pewinternet.org/]

[9] Sharma R, Verma U, Sawhney V, Arora S, Kapoor V. (2006) Trend of Internet Use among Medical Students. JK SCIENCE Vol. 8 No. 2.

[10] Dorup J. Experience and attitudes towards information technology among first-year medical students in Denmark: longitudinal questionnaire survey. J Med Internet Res. 2004; 6(1):e10.

[11] Virtanen JI, Nieminen P. Information and communication technology among undergraduate dental students in Finland. Eur J Dent Educ. 2002; 6(4):147-52.

[12] Jerry V. Glownaik. Medical Resources on the Internet. Ann Intern Med. 1995; 123(2):123-131. 